\title{
Indonesian Tourism Diplomacy to India
}

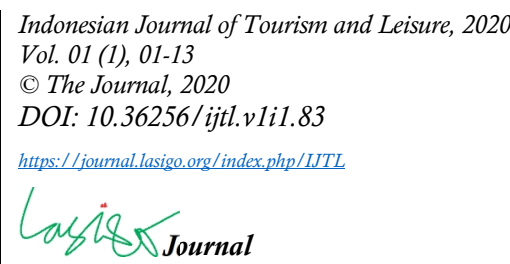

Article History

Received: February 28 $8^{\text {th }}, 2020$

Revised : March $12^{\text {th }}, 2020$

Accepted :March 21 $1^{\text {st }}, 2020$

\begin{abstract}
Anton Minardi
Department of International Relations, Pasundan University, Bandung, West Java abdurrahmananton1975@gmail.com
\end{abstract}

\section{Taufik}

Department of International Relations, Pasundan University, Bandung, West Java taufik@unpas.ac.id

\section{Rini Afriantari}

Department of International Relations, Pasundan University, Bandung, West Java riniafriantari@gmail.com

\section{Neneng Uswatun Hasanah}

Department of International Relations, Pasundan University, Bandung, West Java nenenguhasanah@gmail.com

\begin{abstract}
Nowadays, tourism is one of the sectors that have a significant influence on the development of a country in various fields, including in the economic area and also diplomatic relations among the nations. The tourism sector is the fourth largest foreign exchange earner for Indonesia in 2015. Indonesia, with all its natural wealth and cultural heritage, continually striving to develop the tourism sector through the Ministry of Tourism Indonesia. Indonesia Ministry of Tourism is conducting tourism diplomacy by holding promotions to various countries that have the potential to attract tourists to Indonesia, one of them is India. This article seeks to analyze how Indonesia's diplomacy to attract peoples from India whereas as rapidly developed country in the world. This study used a literature review to analyze Indonesian tourism diplomacy to India. The findings show that through tourism diplomacy, we find that Indonesian attracted India by utilized cultural similarities, has been succeed in increasing tourists' visits from India.
\end{abstract}

Keywords: Indonesian Tourism, Tourism Diplomacy, Cultural Similarities, Tourism Promotion

\section{Introduction}

Diplomacy is a system wherein an art that is adopted from Greek to regulate international relations through a negotiation process which is then harmonized by state actors, is also assumed to be an activity that maintains, promotes and advances the principle of national interest in 
relations between other countries by peaceful means (Roy, 1991). Moving on from the classic relationships of diplomacy emphasizing the security of the territorial interests and maximum benefits of the country itself, now diplomacy integrity refers more to how there is security over political freedom by strengthening cooperation relations with friendly countries. Cooperation among the countries is needed to meet the necessities of life and show their existence in the international world.

Common factors are underlying diplomatic relations between countries in the world, such as geographical proximity, cultural similarity, religion, political system, and historical background. A concrete example of the fulfillment of these factors is in the diplomatic relations between Indonesia and India through multi-track diplomacy, including tourism. On March 3, 1951, Indonesia and India officially opened their foreign relations by signing the Treaty of Peace and Friendship. In the agreement, there is an agreement that representatives of the two countries must often meet to exchange views on matters of mutual interest. The two countries also agreed to settle disputes arising through negotiations as the first step in their resolution.

To strengthen relations between the two countries, in 2005, Indonesia and India agreed to increase the status of bilateral relations to become strategic partners (New Strategic Partnership). The Indonesia-India Strategic Partnership, signed in 2005, has continued to increase in all fields. In 2013, Prime Minister Manmohan Singh paid a state visit to Indonesia. During the visit, President Susilo Bambang Yudhoyono and Manmohan Singh discussed the memorandum of understanding and regional issues such as the global financial crisis, G-20, ASEAN, and increased bilateral cooperation between Indonesia and India. During the visit, it was also agreed that the Strategic Partnership was strengthened through five initiatives, namely: strategic engagement; defense and security cooperation; comprehensive economic partnership; cultural and people-to-people links; and cooperation in responding common.

India and Indonesia are one of the big fast-growing global economies today. India's GDP is estimated to be increase 7.2 percent in 2017-2018 and 7 percent in 2018-2019. India has maintained its position as the third-largest startup base in the world, with more than 4,750 new technologies (IBEF, 2019). This can be a business and investment opportunity because of its large labor base, diverse natural resources, and fundamental economic strength. That is also the reason for Indonesia to establish cooperation in various aspects, especially in the economic element, which in this case, is trade. The two countries decided to give a significant boost to their business and investment relations by focusing on the fields of oil and gas, energy, information technology, and pharmaceuticals. According to Industry Minister Airlangga Hartarto, India is an essential partner for Indonesia (Kementerian Perindustrian RI, n.d.).

In terms of trade, India is Indonesia's 8th largest trading partner. The total value of bilateral trade between the two countries in 2018 reached USD 18.7 billion, while the Indonesia-India trade balance in 2018 was recorded at USD 8.7 billion (Kementerian Perdagangan RI, n.d.). In 2017 foreign investment from India to Indonesia surged to USD 286.6 million and ranked it 16th (CNN, 2019). India is the biggest buyer of crude palm oil from Indonesia. India imported at least 9 million metric tons of CPO throughout 2016, Indonesia's CPO exports to India recorded 5.78 million metric tons at the same time. This means that 64.22 percent of India's CPO imports are supplied by Indonesia (CNN, 2017). India is also one of the countries with the strongest military in Asia and in the world. In 2019 Indian military power was ranked fourth. With 1,362,500 active personnel and 2,100,000 reserve personnel, the country has a large military force (Global Fire Power, 2019). Although India is still categorized as a developing country, this country is brave enough to spend substantial funds for military purposes. In 2011, the scale of Indian military purchases moved from the second-highest level in the world to the highest level, and they were consecutively the highest for seven years (Kompasiana, 2018). India's defense industry is now seen as highly developed. Recognizing these opportunities, Indonesia and India conducted joint military exercises called "Garuda Shakti" held in 2012 in turn (TNI AD, 2018). 
In the current era of globalization, the tourism sector is the largest and most potential sector in financing the global economy. Indonesia and India agreed to develop mechanisms to explore new opportunities to expand tourism opportunities. Both parties are of the view that increasing tourist flows will further enhance bilateral relations between India and Indonesia and also provide the impetus for the growth of the tourism sector in their respective countries. In India, the tourism sector can play an important role in absorbing investment, infrastructure development, and in terms of labor. Tourism has a strategic position in increasing the country's foreign exchange, primarily Indonesia, is known as a country that has a rich and diverse tourism potential. Indonesia, with all its rich natural and cultural diversity has great potential, especially in the tourism sector (Firdaus, 2018). Indonesia's diversity can attract millions of tourists to visit Indonesia. In 2015, Indonesian tourism contributed 10\% of national GDP and ranked fourth as a contributor to national income after oil and gas, coal, and palm oil, which amounted to $93 \%$. In terms of labor, Indonesian tourism accounts for 9.8 million jobs, or $8.4 \%$ (Kementerian Pariwisata RI, 2018).

The cooperation between Indonesia and India is inseparable from the relations between the two countries, which have lasted for quite a long time. Indonesia and India have similarities, especially in cultural aspects. In the 1st century, Indian traders came to Indonesia, indirectly spreading Hinduism and Buddhism in Indonesia. This is evident from the existence of Hindu Buddhist kingdoms and their relics, which still exist today. Indonesia has absorbed many aspects of Indian culture, which ultimately impacted Indonesia's own culture. One of them is Indonesian, which is an absorption of Sanskrit, which is a language that came from India. The proof is that there are relics in the form of inscriptions found in Kutai, East Kalimantan. One of the popular music in Indonesia, dangdut music, also shows the influence of Hindustani / Indian music. The existing Cultural Bridge between India and Indonesia operates at several levels: art, architecture, drama and popular literature, the Indian community in Indonesia, and even the configuration of Indonesian people and their struggle to be free from colonialism (Mishra, 2011). In addition to cultural aspects, Indonesia and India also have similarities in culinary aspects. The most striking resemblance is the use of spices in every Indonesian and Indian cuisine, bearing in mind the two countries are exporters of some spices throughout the world.

The cultural proximity factor is what makes the number of tourists visiting each country. Not a few Indian tourists visit Indonesia either for business trips, attending certain events, or traveling. Most Indian tourists choose Bali to be their destination when visiting Indonesia. The reason is related to the cultural similarities between India and Indonesia, especially Bali. The similarity of the majority of Hindus has a robust cultural closeness between Indian and Hindu communities in Bali.

Most Indian tourists visiting Indonesia enter from Ngurah Rai International Airport, Denpasar Bali. According to the Indonesian Ambassador to India Sidharto R Suryodipuro, so far, Bali has become a strong magnet that can attract Indian tourist visits (Kompas.com, 2018). One factor that has attracted more Indian tourists to Indonesia through Bali is due to the opening of air transport connectivity from Denpasar to various cities in India. On 23 April 2018, the Garuda Indonesia airline officially operated direct flights Denpasar - Mumbai. Another factor is due to the closeness of Hindu culture between the people of India and Bali. According to Bali's Central Statistics Agency (BPS), India contributes the fourth most foreign visitors to Bali after China, Australia, and Japan. It contributes $4.43 \%$ of total international visitors to the Island of the Gods. The increase in visits of Indian tourists to Indonesia is also one of them influenced by the enactment of Presidential Regulation of the Republic of Indonesia No. 21 of 2016 concerning Visa-Free Visit to 169 countries, one of which is India (Pusat Informasi Hukum Kementerian Luar Negeri RI, 2016).

Of the total number of foreign tourists visiting in 2014 - 2018, India has around $2.6 \%$ to $3.8 \%$ annually. In that year, foreign tourists from India ranked seventh (Badan Pusat Statistik, 2017). 
Even so, from the period 2010 to 2018, the number of Indian tourists visiting Indonesia continued to increase. From 2010 to 2018, the number of Indian tourists experienced a rapid increase. In 2010 the number of tourists from India was 110,658 people and continued to increase along with the Indonesian government programs to increase the number of foreign tourists entering Indonesia. In 2018 the number of tourists from India numbered 595,100 people. The most significant increase was in 2017, which was $41.2 \%$. Noted 532,005 tourists from India visited Indonesia in 2017 from before in 2016 tourists from India as many as 376,802 people. Some tourists from India visiting Indonesia are not just for vacation. Many of them came to Indonesia to attend the International Yoga Day, which was celebrated on June 21 and held in several cities in Indonesia. Bearing in mind that Indonesia is one of the initiators of Indian sports celebrations and has been established as a host for four years.

The long-standing relationship between Indonesia and India does not guarantee that the two countries can easily attract tourists to visit their country. The efforts are carried out by each country in order to attract foreign tourists, starting from establishing cooperation carried out through the government, or by diplomacy. In this case, diplomacy is applied not only through the government but also through the community. To bring in foreign tourists from India, the Ministry of Tourism is trying to prepare what is needed by tourists, such as adventure and environmental tour packages, Indian food, and a comfortable nightlife atmosphere (Dinas Pariwisata dan Kebudayaan, 2015). Considering that the government has a vital role in making various regulations or policies which will be implemented to improve the tourism sector, beneficial not only for the state but also for the local community ((Taufik, 2016). With the similarity of culture, history, and bilateral relations that have been established, the author wants to examine whether this can affect the increasing number of tourists from India in Indonesia

\section{Literature Review}

In the study of international relations, there must be communication, a tool which is then used in international relations, namely diplomacy. Diplomacy is the practice of conducting negotiations between countries through official representation and is one of the critical instruments in implementing a country's foreign policy. S.L. Roy explained diplomacy as the main tool in achieving national interests related to other countries or international organizations (Roy, 1991). Through this diplomacy, a country can build an image or image about itself to develop bargaining value or state branding (Effendi, 2008). Diplomacy is usually carried out officially between state governments, but it can also be informal through informal institutions or between residents or between communities of different countries.

There are types of diplomacy, such as political diplomacy, economic diplomacy, cultural diplomacy, education diplomacy, military diplomacy, tourism diplomacy, and media. Tourism diplomacy with media used by Indonesia-India relations is classified as public diplomacy, which is one of the instruments of soft power. This study called tourism diplomacy because, in diplomacy, it has multi-tracks of diplomacy government to government, government to nongovernment organization, or government to the individual, or vice versa, which various ways including tourism diplomacy.

In this case, diplomacy is also applied by Indonesia in promoting tourism to develop and introduce existing tourism to other countries. Diplomacy by Indonesia in the form of organizing programs that can attract foreign tourists to come to Indonesia, including Indian tourists.

Tourism has become one of the leading strategies of the government in developing countries by utilizing natural resources. The government uses diplomacy as a tool to promote the country's tourism. This is following the concept of Taufik explained that the government plays an essential role in creating various regulations and strategic plans (Taufik, 2016). James Elliot stressed the importance of government; it is merely the government that strives for political stability, security, legality, and financial framework needed in tourism (Elliott, 1997). Quoting Joan Henderson's 
opinion from the thesis written by Taufik, Henderson said that talking about tourism is usually related to machinery and government policy. With this thought, planning and formal policies regarding tourism can be seen from the government's consideration (Taufik, 2014).

In this study, we used the review of the literature as a framework compiled to classify sources of data and general information studied in the research. Based on the literature search, we find several studies that can support the work of this thesis serving as a guide and sharpen analysis.

The first one is the study conducted by Taufik, explaining how important the role of government is in making regulations or policies to improve the tourism sector that benefits the state and local communities. In managing tourism, exceptional management is needed prepared by the Palu city government. One of the ways carried out by the Palu city government to add value from the Palu bay is through the construction of segmentation along the Talise coast, Taman Ria, and the Fishermen's Village with the concept of Waterfront (Taufik, 2016). Second, Astari \& Dewi studied the efforts of Indonesian public diplomacy in increasing the number of South Korean tourists visiting Indonesia. The results of this study explain that it turns out that diplomatic initiatives undertaken by Indonesia in promoting Indonesian tourism in South Korea have not been maximized, as evidenced by the achievement of the government's target to bring in 400 thousand tourists from South Korea in 2016 (Astari \& Dewi, 2017). Third, Budi reviewed and discussed the role of the ASEAN Tourism Forum (ATF) to increase foreign tourist arrivals in Indonesia. Its marketing strategy began by introducing ASEAN branding, namely "Southeast Asia Feel the Warmth" as a symbol of the ASEAN Single Destination. In this study also explained that the ATF could function as an Investment Cooperation Forum and Tourism Standardization Forum. The results of this study stated that ATF has a positive role in increasing foreign tourist arrivals in Indonesia, various programs that have been carried out through ATF such as tourism promotion in various countries to determine tourism standardization in the ASEAN region have a positive influence on increasing foreign tourist arrivals in Indonesia (Budi \& Pahlawan, 2016).

\section{Method}

The research used a qualitative approach with a case study method. Qualitative methods, according to Creswell, were methods to explore and understand the meaning that by a number of individuals or groups of people ascribed to social or humanitarian problems (Creswell, 2012). The main objective of qualitative research was to understand (to understand) social phenomena or phenomena by focusing more on the complete picture of the event being studied. The case study research method was an in-depth research on individuals, one group, one organization, and so on within a particular time. This research method aims to obtain an in-depth description of an entity.

In this case, the connection with the discussion is the writer outlined how the Indonesian government efforts in increasing the number of tourists from India and describes the level of Indian tourist visits to Indonesia especially from 2014 to 2018.

\section{Results}

\subsection{Indonesian Tourism}

Indonesia is one of the largest archipelago countries in the world, consisting of thousands of large and small islands connected by strait and sea. The total area of the ocean in Indonesia is wider than the total land area. With its breadth, Indonesia stores many wonderful natural resources both on land and under the sea. No wonder Indonesia has many beautiful places, especially in the beach sector. Because of its natural beauty, Indonesia has become a tourist destination by local and foreign tourists. Not only that, Indonesia is also rich in culture, but various tribes in Indonesia with their respective characteristics also make cultural diversity in Indonesia. The natural and cultural wealth is an essential part of Indonesian tourism. With all its variety and 
beauty, Indonesia has made tourism an important one in the creative-based services sector. Indonesia, with all its tourism potential, is expected to be able to contribute to the welfare of the people, especially Indonesia has a unique geography.

The location of Indonesia, in the tropics, makes the land in Indonesia very fertile, so it is very suitable to be used as an agricultural and plantation country. The World Travel \& Tourism Council (WTTC) ranks Indonesian tourism 9th in the world based on four indicators, namely total GDP of travel and tourism, foreign visitor expenditure, domestic expenditure, and capital investment in travel and tourism. Not only land, Indonesian sea is also known for its beauty in the world. Indonesia is among the ten best countries for surfing, according to Lonely (Lonely Planet, 2019). Indonesia has also obtained some awards in the tourism sector, such as the award as the World's Best Halal Tourism Destination 2015 and the World Best Halal Honeymoon Destination 2015 for Lombok, and the World Best Family-Friendly Hotel 2015 for Sofyan Hotel. The beauty of the Indonesian sea is also known to the world as a paradise by divers from all over the world. It is evidenced by the selection of several diving spots in the Indonesian sea as World's Top100 Dive Site, according to Scuba Travel. National Geographic also places Borobudur Temple in third place in World's Iconic Adventures worth the Effort.

Tourism has a strategic position in increasing the country's foreign exchange. Even in 2014, Indonesia's tourism industry was able to contribute around the US $\$ 10$ billion in foreign exchange. The position became number four after oil, coal, and palm oil (Kementerian Komunikasi dan Informatika RI, 2015). This makes tourism an important economic sector in Indonesia. Foreign exchange from the tourism sector in 2016 amounted to the US $\$ 13.5$ billion and came in second after CPO of US \$ 15.9 billion. The tourism sector also contributes to the region's original income and also the revenue generated from tourism businesses that are developed as well as opening up massive employment opportunities and high employment. Not only economically, the contribution of tourism also has a broad dimension, namely social, political, cultural, regional, and environmental aspects. In socio-political terms, tourism can foster pride in the natural and cultural wealth it possesses so that it can promote and strengthen the love of the motherland. According to the Ministry of Tourism in the 2018-2019 Strategic Plan, the tourism sector has a strategic position in various development policies, especially for the Indonesian state, tourism assets, to be strengthened and empowered as a pillar of the country's economy (Kementerian Pariwisata RI, 2019).

The United Nations Organization for Tourism or the United Nations World Tourism Organizations (UNWTO) states that the tourism sector is a leading sector (Tourism is a Leading Sector) and is one of the important keys to developing the country and improving welfare for the people (Kementerian Pariwisata RI, 2019). However, weaknesses are still found in Indonesian tourism. Lack of adequate infrastructure in Indonesia has become an ongoing problem, from basic infrastructure such as water, sanitation, telecommunications, as well as significant infrastructure such as roads and airports that still need to be improved. Lack of connectivity between islands indicates that a number of Indonesian regions, great tourism potential, cannot be achieved easily. Sujai reviewed that Indonesia also still has weaknesses in terms of marketing and packaging for tourism. According to him, despite having a beautiful and diverse tourist destination, but without proper marketing and packaging, the results will not be maximized (Sujai, 2016).

In addition to having natural resources that are known to be beautiful, Indonesian cuisine is also known for having a powerful taste. Although there are influences from several countries in their culinary, it can be said that the richness of the types of cuisine in Indonesia is a reflection of the diversity of cultural and traditional archipelago. Almost all culinary in Indonesia uses a variety of spices in the manufacturing process, considering that Indonesia is one of the most considerable spice producing and exporting countries in the world. This culinary is also one of the attractions for foreign tourists to come to Indonesia and experience the culinary directly. 
Indonesian cuisine has also been known in the world, including fried rice, meatballs, satay, rendang, and tempe.

\subsection{Number of Foreign Tourists Entering Indonesia}

In The attractiveness in the tourism sector owned by Indonesia has brought tourists from various countries in the world. Indonesian tourism has become one of the destinations that are in high demand by multiple tourists because there is natural beauty in it. In addition to its millions of natural beauty charms, Indonesia is also rich in cultural tourism, as evidenced by the existence of historical relics as well as a variety of customs and arts and cultural communities. The vast potential of Indonesian tourism makes many foreign tourists come to Indonesia. From 2014 to 2018 , it was noted that international tourists coming to Indonesia always experienced an increase every year.

Graph 1. Number of Foreign Tourists to Indonesia

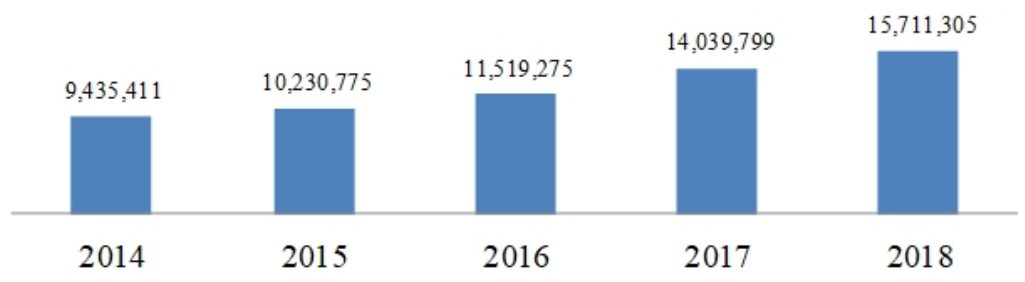

Source : Badan Pusat Statistik, 2018

The increase in the number of foreign tourists in Indonesia is also directly proportional to foreign exchange income continuing to increase. The contribution of the tourism sector can be measured by several key indicators. The first is the visit of both domestic and foreign tourists. Second is the expenditure of tourists visiting. The latter is private sector investment and government investment, as well as government spending in the field of tourism, such as tourism promotion and tourism development.

Graph 2. Foreign Exchange Earnings

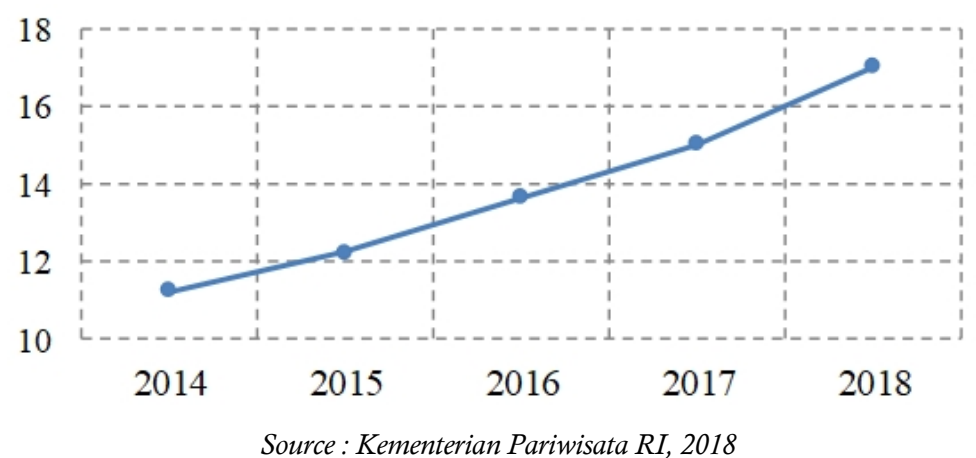

Of the various foreign tourists coming to Indonesia, India is one of the contributors to foreign tourists visiting Indonesia. Tourists from India have a growing number of tourists. Of the total number of foreign tourists entering Indonesia from 2014 to 2018, India ranks seventh, and every year, India contributes $3 \%$ to $4 \%$ of the total foreign tourists visiting and its foreign exchange earning of Indonesia. 
Graph 3. Number of Indian Tourists in Indonesia

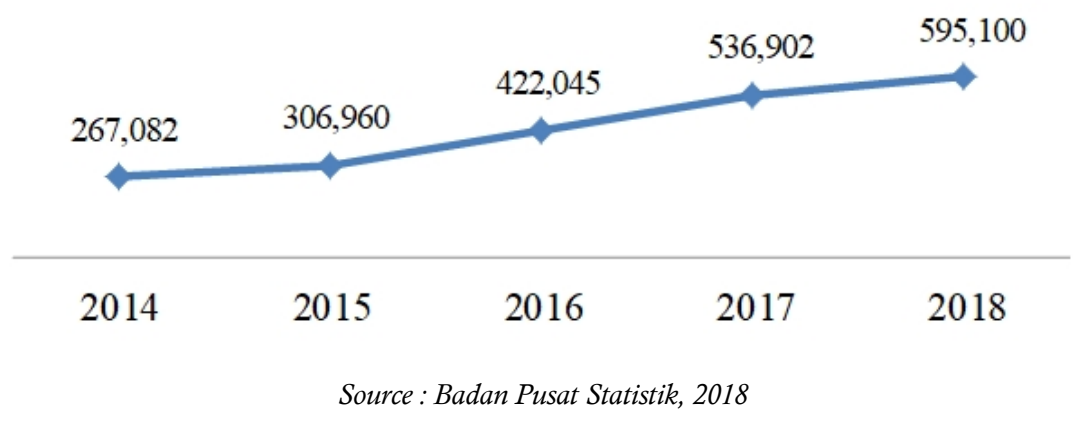

The increasing number of Indian tourists in Indonesia is a long process. It is one of the impacts of the policies made by both the Indonesian and Indian governments in enlarging their cooperation. This is proof that Indonesian tourism diplomacy to India, successful to increase tourists' visitor especially from India, and earn country income.

\section{Discussion}

\subsection{Indonesian Attraction}

The natural wealth possessed by Indonesia is one of the main attractions for various tourists who will come. Existing cultural heritage in Indonesia in the form of art and culture is a wealth that can be enjoyed by both domestic and foreign tourists. In Indonesia, you can find many historical and cultural relics in various regions. Some of Indonesia's cultural heritage have even been recognized by the United Nations Educational, Scientific, and Cultural Organization (UNESCO). This is an encouragement, especially for the government, to maintain the sustainability of Indonesian tourism, value in the world. The wealth of resources also in culinary owned by Indonesia can attract tourists from various countries to come to Indonesia.

Most foreign tourists come to Indonesia because they are interested in Indonesia's tourism. Beaches, especially in Bali and Lombok, are considered the most popular vacation spots for foreign tourists. Another attraction is the presence of several national parks such as the Komodo National Park, a UNESCO world heritage site, and Tanjung Puting National Park in Borneo, the largest home for the orangutan population in the world. Indonesia's location in the Ring of Fire also makes Indonesia known to have areas with some of the most active volcanoes in the world. As the largest archipelago country in the world, Indonesia also has many tourist sites that have not been touched by many people. For tourists who love learning culture, Indonesia is also a favorite place to visit. Diverse cultures in Indonesia make each region in Indonesia have different cultures, customs, and habits. Indonesia is also known to be one of the countries with a friendly population, especially to foreign tourists who come.

With the natural wealth, culture and culinary wealth of Indonesia, as well as the recognition of the beauty of Indonesia through several awards in the tourism sector obtained by Indonesia, making domestic and foreign tourists interested in coming to Indonesia to enjoy the wealth in Indonesia directly. The location of Indonesia, on the equator, also makes Indonesia to be a tropical climate so that it always gets sunshine every day throughout the year. With so many beaches in Indonesia, Indonesia is a favorite destination for tourists, well known foreign tourists really like basking in the sun to make their skin darker.

The existence of Presidential Regulation No. 21 of 2016 concerning visa-free policies for 169 countries makes it easy for foreign tourists to visit Indonesia without the need first to obtain a visa. Friendly character possessed by residents in Indonesia also makes foreign tourists interested in coming to Indonesia, bearing in mind that not all countries in the world have friendly 
residents, especially for foreign tourists. In addition, Indonesia is also known to have relatively lower living costs compared to neighboring countries such as Singapore.

\subsection{Potency of Indian Tourists for Indonesia}

India is one of the countries that Indonesia has targeted in terms of establishing cooperative relations. The Indian economy, great potential resources, is strengthened by the presence of an industry with a strong technological basis. Economists use income thresholds that define middleclass people i.e. those who live on $\$ 2$ to $\$ 4$ per person per day are said to be middle-low, and those living on $\$ 6$ to $\$ 10$ per person per day are said to be upper-middle class (Biswas, 2017). Using this threshold, it has been found that the middle class in India has been dominated by the upper caste (Krishnan \& Hatekar, 2017). India is also one of the countries with the second largest population in the world. India's population is equivalent to $17.74 \%$ of the total world population (Worldometers, 2019).

The potential of travel in India is huge, considering that India is now one of the fastestgrowing economies and one of the world's most populous countries. It is known that outbound and domestic tourism in India from 2015 to 2016 grew by $8.5 \%$. That is what makes India a potential tourism market and target for Indonesia.

Graph 4. Outbound Tourism of India

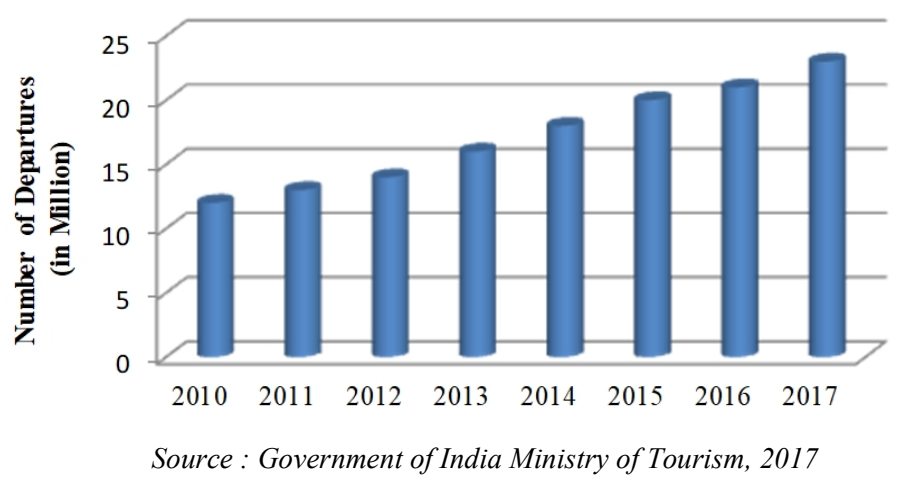

\subsection{Indonesia's Tourism Diplomacy Strategy}

Realizing the potential of the country, the Indonesian government seeks to develop tourism potential, one of which is to attract more tourists who come to Indonesia. Indonesian diplomacy employed tourism diplomacy with the government programs, using social media and similarities approach such as Hindu follower approach, attracted tourists who came to Indonesia with historical heritages and especially to Bali.

In this effort, the Ministry of Tourism has formulated a marketing strategy through the DOT (Destination - Origin - Time) and BAS (Branding - Advertising - Selling) marketing strategy framework. Indonesian tourism products are marketed through various POSE (Paid Media Owned Media - Social Media - Endorser) media channels (Kementerian Pariwisata RI, 2019). As for the promotion period, the Ministry of Tourism will formulate a POP (Pre-On-Post) strategy. Pre Event is a promotional effort before the day of the event, On Event is support through promotion items, and Post Event which is reporting activities in the form of writing articles, testimonies, etc. as an expression of appreciation for the activities carried out (Kementerian Pariwisata RI, 2015: 60). In 2017, the Ministry of Tourism had ten strategic programs, namely: Digital tourism (e-Tourism) and millenial tourism, homestay, air connectivity (airlines), branding, Top-10 origination, Top-3 main destinations (15 Branding Destinations), development of 10 priority destinations or 10 new Bali, HR competency certification and tourism conscious 
movement, increased tourism investment, crisis center management (Kementerian Pariwisata RI, 2019).

Branding used by Indonesia in introducing Indonesian tourism to tourists, especially foreign tourists, is through Wonderful Indonesia. The Indonesian government often organizes and participates in tourism exhibitions in various countries to promote tourism. Wonderful Indonesia is also promoted through social media, paid media. In addition, the promotion is done by posting Wonderful Indonesia advertisements in various countries using Open Great Bus, installed on duty-free boxes, glass gate stickers, and also on digital screens.

\subsection{Implementation of Indonesia's Tourism Diplomacy Strategy in India}

Seeing the potential of tourists owned by India, then conducted diplomacy by Indonesia for India. Diplomacy carried out by Indonesia is an implementation of the tourism marketing strategy that has been formulated by the Ministry of Tourism, namely DOT (Destination - Origin - Time) and BAS (Branding - Advertising - Selling). The Indonesian government implements the tourism marketing strategy through programs conducted in India and in Indonesia. Some promotional programs carried out in India, namely, in 2015, the Ministry of Tourism held a Wonderful Indonesia Promotion in India. The promotion took place at Select City Mall, New Delhi, one of the most popular shopping centers in New Delhi. To attract the attention of shopping center visitors, the Ministry of Tourism packs these promotional activities with a variety of strategies. For instance, presenting various kinds of arts and charms of traditional Indonesian culture such as traditional dance, holding several games as well as coffee tasting.

The Indonesian Embassy in New Delhi by inviting Indian PPI and Indonesian diaspora in India held the Namaste Wonderful Indonesia Festival in Nehru Park in 2016. The event, held during the Diwali celebration succeeded in attracting the attention of many visitors, bearing in mind that Diwali is one of the biggest celebratory festivals in India so that many Indians and International tourists come to the festival. The program featured many traditional dances and Indonesian regional songs by PPI India. In addition, Indonesian specialties are also provided such as satay and gado-gado.

On September 7, 2017, the Ministry of Tourism and Consulate General of the Republic of Indonesia in Mumbai once again held a Wonderful Indonesia Promotion (PWI) event at the Diplomatic Reception in Mumbai, India. The activity is a series of commemorations of the $72^{\text {nd }}$ Indonesian Independence Day held at the Consulate General in Mumbai as well as a media for the promotion of Indonesian art and culture in India. The Wonderful Indonesia team also took part in the most prominent tourism industry exhibition in 2017 for the market in South Asia, namely "SATTE" by collaborating with 28 tourism industries. Another strategy is to implement collaboration with the largest travel agency in India, one of which is with MakeMyTrip. The Ministry of Tourism, together with MakeMyTrip, opened a booth at Ambience Mall New Delhi on a mission to introduce various tourist sites that are the mainstay in Indonesia in 2017.

Besides conducting tourism promotion activities by holding promotional programs and participating in exhibitions as well as festivals in India, the Indonesian government also holds tourism promotions in the country. In 2018, Indonesia hosted the 4th International Yoga Day celebration. The celebration of International Yoga Day is used by Indonesia to promote Indonesian tourism since the ceremony is the biggest Yoga Day celebration so that many tourists come to follow it. In this celebration, Indonesia also made use of it by holding culinary tours, especially vegetarian cuisine, as an attraction to increase foreign tourist arrivals, especially tourists from India.

Not only through exhibitions, festivals, or other media, in promoting tourism, the Indonesian government also utilizes various other media channels such as paid media, owned media, social media, and endorsers. President Joko Widodo is considered a reliable "endorser" and has an impact on encouraging tourists, especially Indian tourists, to visit Indonesia. Recalling President 
Joko Widodo often held meetings with Indian Prime Minister Narendra Modi. PM Narendra Modi also made several visits to Indonesia. During the visit, the Indonesian government, through President Joko Widodo, indirectly promoted the wealth of tourism owned by Indonesia.

\section{Conclusion}

Realizing the potential of the country, Indonesia, through the Ministry of tourism diplomacy in tourism to various countries, one of which is India. India is currently the second-most populous country and is one of the fastest-growing economies in the world. It is known that outbound tourism in India is also increasing every year. That makes it a unique opportunity for Indonesia to make India a potential tourism market and target.

Diplomacy conducted by Indonesia is an implementation of the tourism strategy that has been formulated by the Ministry of Tourism, namely DOT (Destination - Origin - Time) and BAS (Branding - Advertising - Selling). The diplomacy employed natural resources, similarities approach, cultural heritages, travel agents and airline cooperation, and social media branding.

The Indonesian government promotes various Indonesian tourism destinations, especially those that become priority destinations in India through various means, such as by attending multiple festivals, tourist exhibitions, and establishing cooperation with travel agents and airlines. The tourism diplomacy is implemented by the Indonesian government through programs conducted in India and Indonesia.

The Ministry of Tourism organizes promotional programs held in India and in Indonesia. One of them is by Promotion of Wonderful Indonesia. The effort is aimed at attracting tourists from India to come to Indonesia. The tourism ministry also cooperates with some of the most extensive travel and tour operator companies in India. The tourism ministry can be said to be successful in its efforts to increase the number of tourists from India who come to Indonesia. This can be shown by the graph of the number of tourists from India visiting Indonesia increasing every year during 2014 to 2018. Indian tourists visiting Indonesia increase from 267,082 to 595,100 in 2018.

\section{Acknowledgement}

This is independent research as an academic researcher in the International Relations Department of Pasundan University.

\section{Funding}

The research is self-funding by authors with the provision of accommodation from Pasundan University.

\section{Conflicts of Interest.}

There is no conflict of interests moreover, this research as an academic project and a recommendation to the government

\section{References}

Astari, N. L. P. D. C., Dewi, M. A. (2017). Upaya Diplomasi Indonesia dalam Meningkatkan Jumlah Kunjungan Wisatawan Korea Selatan Ke Indonesia. Studi Diplomasi Dan Keamanan, 9(2), 1-23.

Badan Pusat Statistik. (2017). International Visitor Arrivals Statistics.

Biswas, S. (2017). Is India's Middle Class Actually Poor? BBC. Retrieved from https://www.bbc.com/news/world-asia-india-41264072

Budi, A. S., \& Pahlawan, I. (2016). Peran ASEAN Tourism Forum Dalam Meningkatkan Kunjungan Wisatawan Asing Di Indonesia (2009-2013). Jurnal Online Mahasiswa Fakultas Ilmu Sosial Dan Ilmu Politik Universitas Riau, 3(2), 1-15. 
CNN. (2017). India Disebut Masih Butuh Pasokan CPO dari Indonesia. Retrieved from https://www.cnnindonesia.com/ekonomi/20170912135127-92-241157/india-disebutmasih-butuh-pasokan-cpo-dari-indonesia

CNN. (2019). Indonesia "Rayu" India Investasi Sektor IT dan Farmasi. Retrieved from https://www.cnnindonesia.com/ekonomi/20190320071255-92-378903/indonesia-rayuindia-investasi-sektor-it-dan-farmasi

Creswell, J. W. (2012). Research Design Pendekatan Kualitatif, Kuantitatif dan Mixed. Yogyakarta: Pustaka Pelajar.

Dinas Pariwisata dan Kebudayaan. (2015). Promosi "Wonderful Indonesia" Digelar di Mumbai India.

Effendi, T. D. (2008). E-Diplomacy Sebagai Sarana Promosi Potensi Daerah kepada Dunia Internasional E-Diplomacy Sebagai Sarana Promosi Potensi Daerah, (1), 56-68.

Elliott, J. (1997). Tourism: Politics and Public Sectors Management. London: Routladge.

Firdaus, F. (2018). Potency of Integrated Cultural Tourism Development at Maninjau Lake Area, West Sumatera. Mimbar: Jurnal Sosial Dan Pembangunan, 34(1), 72-82.

Government of India Ministry of Tourism. (2018). India Tourism Statistics 2018.

Global Fire Power. (2019). India Military Strength. Retrieved from https://www.globalfirepower.com/country-military-strength-detail.asp?country_id=india

IBEF. (2019). About Indian Economy Growth Rate \& Statistics. Retrieved from https://www.ibef.org/economy/indian-economy-overview

Kementerian Komunikasi dan Informatika RI. (2015). Saatnya Kembangkan Potensi Pariwisata Indonesia.

Kementerian Pariwisata RI. (2015). Laporan Akuntabilitas Kinerja Kementerian Pariwisata Tahun 2015

Kementerian Pariwisata RI. (2018). Capaian Sektor Pariwisata 3 Tahun Jokowi-JK. Kementerian Pariwisata RI. (2019). Rencana strategis 2018-2019.

Kementerian Perdagangan RI. (n.d.). Neraca Perdagangan Indonesia dengan India Periode: 2014 - 2019.

Kementerian Perindustrian RI. (n.d.). Selain Industri Farmasi, RI Incar Investasi India di Tiga Sektor.

Kompas.com. (2018). "Beyond Bali" Dipromosikan di India. Retrieved from https://travel.kompas.com/read/2018/05/30/090700327/-beyond-bali-dipromosikan-diindia-

Kompasiana. (2018). Mengintip Kekuatan Militer India dan Ambisi Berkembang Ke Timur dengan Kebijakan "Act East." Retrieved from https://www.kompasiana.com/makenyok/5a5de806ab12ae145c6dc882/mengintip-

kekuatan-militer-india-dan-ambisi-berkembang-ke-timur-dengan-kebijakan-act-east?page=all

Krishnan, S., \& Hatekar, N. (2017). Rise of the New Middle Class in India and Its Changing Structure. Economic and Political Weekly, 52(22), 40-48.

Lonely Planet. (2019). Catch a wave in the 10 best countries for surfing. Retrieved from https://www.lonelyplanet.com/travel-tips-and-articles/catch-a-wave-in-the-10-bestcountries-for-surfing/40625c8c-8a11-5710-a052-1479d27502bd

Mishra, R. (2011). Mosaics of Cultures: Investigating the Role of Cultural Linkages in India Indonesia Relations. IDSA ISSUE BRIEF.

Pusat Informasi Hukum Kementerian Luar Negeri RI. (2016). Perpres 21 thn 2016 tentang Bebas Visa Kunjungan

Roy, S. L. (1991). Diplomasi. Jakarta: Rajawali Press.

Sujai, M. (2016). Strategi Pemerintah Indonesia Dalam Menarik Kunjungan Turis Mancanegara. Kajian Ekonomi Keuangan, 20(1). 
Taufik. (2014). Kerja Sama Pariwisata ASEAN: Telaah atas Strategic Direction ke-3 dari ASEAN Tourism Strategic Plan (ATSP) 2011-2015. UGM.

Taufik. (2016). Governance Value Chain : Pengembangan Wisata Teluk Palu, VI(2), 5162.

Worldometers. (2019). India Population. Retrieved from https://www.worldometers.info/worldpopulation/india-population/ 